\title{
UPAYA KELUARGA PRA SEJAHTRA DALAM MEMBENTUK KELUARGA SAKINAH
}

\author{
Badrudin \\ Universitas Islam Negeri Syarif Qasyim Riau \\ Email :badrudin@gmail.com
}

\begin{abstract}
This research is a field of research that discusses the concept of harmonious family in pre Sejahtra family perspective. A case study in Jombang district administrative districts Jombatan Jombang. To answer these problems, this study uses qualitative research methods that are descriptive of the data that already we get some understanding and harmonious family related issues in the perspective of the family pre Sejahtra. One indicator of the lack sakinahan or disharmony of a family is the percerain. This is a lot going on and we find in our society. That percerain become commonplace and common. Although basically a normative text in either the Qur'an or the hadith does not forbid percerain. But that does not mean religion gives the green light for us all to do percerain easily. Memiberikan religion but also a warning that percerain is a lawful act of the most hated by Allah. Not only that religious notabenenya judiciary as a representation of Islamic law is also currently operate principle to reconcile and complicate their percerain. That means that the religion calls for kesakinahan and harmony in the family and does not want just the execution percerain either divorce or the divorce contested divorce. Pursuant to statistical data, that the lack of a family sakinahan indicator of percerain much influenced by economic factors, because one person's basic capital menage is the availability of a clear source of income to meet living bebutuhan financially. The survival of the family, among others, determined by the smoothness of the economy, otherwise chaos in the family triggered by the poor economy lancer. From the present study, there are some interesting fact found in the field, namely the existence of pre Sejahtra were able to realize a harmonious family mawadah wa Rahmah. Precisely with a mediocre economy is, they take a lot of wisdom and ibrah from a wealthy family, that turned out to matter not be able to ensure the establishment of harmonious family without an underlying sense of compassion and understanding high as between both partners. The concept is applied pre Sejahtra family in building a harmonious family is by instilling gratitude for what has been given or bestowed by Allah. Always Qona'ah with revenue earned and never complained with all the troubles. As well as looking at trouble as happiness.
\end{abstract}


While efforts in the realization of pre Sejahtra harmonious family is a way to understand each other and understanding between both partners, especially in matters of daily earnings. And the most important is to fortify the family with moral and spiritual message.

Keywords: Pre Sejahtra family, family Sakinah

\begin{abstract}
Abstrak
Penilitian ini merupakan penelitian lapangan yang membahas tentang konsep keluarga sakinah dalam prespektif keluarga pra sejahtra. Sebuah studi kasus di kelurahan jombatan kecamatan jombang kabupaten jombang. Untuk menjawab permasalahan tersebut, penelitian ini menggunakan metode penelitian kualitatif yang bersifat deskriptif mengenai data-data yang Sudah kita dapatkan serta beberapa pemahaman terkait dengan masalah keluarga sakinah dalam prespektif keluarga pra sejahtra. Salah satu indikator ketidak sakinahan atau ketidak harmonisan sebuah keluarga adalah terjadinya percerain. Hal inilah yang banyak terjadi dan kita temukan di dalam kehidupan masyarakat kita. Bahwa percerain menjadi hal yang lumrah dan biasa dilakukan. Walaupun pada dasarnya secara teks normative baik dalam alquran atau dalam hadits tidak mengharamkan percerain. Namun itu bukan berarti agama memberikan lampu hijau kepada kita semua untuk melakukan percerain dengan mudah. Melainkan agama juga memiberikan peringatan bahwa percerain adalah perbuatan halal yang paling dibenci oleh Allah. Bukan hanya itu lembaga peradilan agama yang notabenenya sebagai representasi dari hukum islam juga meberlakukan asas untuk mendamaikan dan mempersulit adanya percerain. Itu artinya bahwa agama menghendaki adanya kesakinahan dan keharmonisan dalam keluarga dan tidak menghendaki begitu saja terjadinya eksekusi percerain baik itu cerai gugat ataupun itu cerai talak. Berdasrkan data statistic, bahwa ketidak sakinahan keluarga dengan indicator adanya percerain banyak dipengaruhi oleh faktor ekonomi, sebab salah satu modal dasar seseorang berumah tangga adalah tersedianya sumber penghasilan yang jelas untuk memenuhi bebutuhan hidup secara finansial. Kelangsungan hidup keluarga antara lain ditentukan oleh kelancaran ekonomi, sebaliknya kekacauan dalam keluarga dipicu oleh ekonomi yang kurang lancer. Dari penelitian kali ini, ada beberapa kenyataan menarik yang ditemukan di lapangan, yaitu adanya keluarga pra sejahtra yang mampu mewujudkan keluarga sakinah mawadah wa rahmah. Justru dengan ekonomi yang pas-pasan inilah, mereka banyak mengambil hikmah dan ibrah dari keluarga yang kaya, bahwa ternyata materi tidak mampu menjamin terbentuknya keluarga sakinah tanpa di dasari rasa kasih sayang
\end{abstract}


dan pengertian yang tinggi antra kedua pasangan. Adapun konsep yang diterapkan keluarga pra sejahtra dalam membangun keluarga sakinah adalah dengan menanamkan rasa syukur terhadap apa yang sudah diberikan atau dikaruniakan oleh Allah swt. Selalu Qona'ah dengan penghasilan yang didapatkan dan tidak pernah mengeluh dengan semua kesusahan. Serta memandang kesusahan sebagai kebahagian. Sedangkan upaya keluarga pra sejahtra dalam mewujudkan keluarga sakinah adalah Dengan cara saling mengerti dan memahami antara kedua pasangan khususnya dalam masalah penghasilan sehari-hari. Serta yang paling penting adalah dengan cara membentengi keluarga dengan pesan moral dan spiritual.

Kata Kunci : Keluarga Pra Sejahtra, Keluarga Sakinah

\section{Pendahuluan}

Perkawinan dalam prespektif hukum Islam merupakan sebuah perjanjian yang sangat agung dan sakral (mitsaqon gholidzon). Sehingga terminologi tersebut berdampak pada komitmen antara kedua pasangan, yang bertujuan untuk membina dan mewjudkan kehidupan rumah tangga yang sakinah. Secara etimologi sakinah diambil dari kata sakana yaskunu yang berarti tempat tinggal yang juga sering diartikan sebagai ketenangan, ketentraman kenyaman. Sedangkan secara istilah sakinah berarti ketenangan atau ketentraman yang tercipta dalam kehidupan rumah tangga. Kata sakinah dalam AlQuran disebutkan sebanyak enam kali yaitu pada surat al-Baqarah ayat 248, surat at-Taubah ayat 26 dan 40, surat al-Fath ayat 4, 18 dan 26. dalam ayat-ayat tersebut dijelaskan bahwa sakinah itu didatangkan Allah swt kedalam hati para Nabi dan orang-orang beriman agar tabah dan tidak gentar menghadapi tantangan dan rintangan, ujian, cobaan maupun musibah. Sehingga sakinah dapat juga dipahami dengan sesuatu yang dapat memuaskan dan menyenangkan hati.

Memahami urgensitas keluarga sakinah dalam konteks kekinian merupakan suatu yang sangat di idealkan oleh kebanyakan keluarga di muka bumi ini, sebab di tengah maraknya tindak kekerasan dalam rumah tangga dan tingginya angka percerain di berbagai Pengadilan Agama, keluarga sakinah menjadi solusi yang paling tepat yang harus di sosialisasikan dan bahkan harus di ekspresikan dalam bentuk action atau tindakan. Sehingga sebagai konsekuensinya tindak kekerasan dan tingginya angka percerain dapat diminimalisir melalui program sosialisasi keluarga sakinah. 
Adapun salah satu indicator ketidak sakinahan atau ketidak harmonisan dalam sebuah keluarga dapat dilihat dari faktor tingginya angka percerain yang banyak terjadi dan kita temukan di dalam kehidupan masyarakat. Ini artinya bahwa percerain menjadi hal yang lumrah dan biasa dilakukan. Walaupun pada dasarnya secara teks normative baik dalam al-Qur'an atau dalam hadits tidak ada satu tekspun yang mengharamkan perceraian. Namun itu bukan berarti agama memberikan lampu hijau kepada kita semua untuk melakukan percerain dengan mudah. Melainkan agama juga memberikan peringatan bahwa percerain adalah perbuatan halal yang paling dibenci oleh Allah. Bukan hanya itu lembaga peradilan agama yang notabenenya sebagai representasi dari hukum Islam di Indonesia juga meberlakukan asas untuk mendamaikan dan mempersulit adanya percerain. Itu artinya bahwa agama Islam ataupun Negara menghendaki adanya kesakinahan dan keharmonisan dalam keluarga dan tidak menghendaki begitu saja terjadinya eksekusi percerain baik itu cerai gugat ataupun itu cerai talak.

Ketika dipahami bahwa percerain merupakan salah satu indicator ketidak sakinahan dalam membangun sebuah keluarga. Maka yang menjadi pembahasan serius sebenarnya akar masalah dari ketidak harmonisan yang berdampak pada percerain yang terjadi di masyarakat. Menurut data statistic yang terjadi di Pengadilan Agama bahwa diantara faktor-faktor yang menyebabkan terjadinya percerain adalah sebagi berikut, tidak ada tanggung jawab ekonomi 739, pasangan selingkuh dan hadirnya pihak ketiga 52, krisis moral 32, dan lain-lain. Diantara beberapa faktor yang kami sebutkan, faktor ekonomi yang mempunyai posisi paling dominan tingkat yang menyebabkan terjadinya percerain. Lantas bagaimana dengan kehidupan masyarakat pra sejahtera yang tergolong tidak mampu dalam segi ekonomi. Apakah kehidupan mereka cukup bahagia dan sakinah. Padahal kalau kita mencoba melihat dan membaca lebih dalam l; lagi tentang kehidupan masyarakat pra sejahtra baik di perkotaan ataupun di pedesaan, mereka cukup memperhatikan. Bagaimana tidak, kategorisasi pra sejahtera yang dikembangkan oleh pemerintah dengan program BKKBN mendefinisikan masyarakat pra sejahtera adalah masyarakat yang hanya mampu makan sehari sekali, apabila sakit tidak mampu untuk berobat dibalai kesehatan kecuali dengan askin (asuransi kesehatan). Rumah yang ditempati tidak beratap atau mempunyai dinding yang layak, semua anak yang 
berumur 7-15 tidak bersekolah, tidak mempunyai pekerjaan tetap. Namun disisi lain mereka juga mempunyai tanggung jawab yang cukup besar untuk mewujudkan sebuah keluarga yang ideal yaitu sakinah mawadah dan rahmah. Walaupun pada dasarnya materi bukanlah faktor utama dalam membangun dan mewujudkan keluarga sakinah, akan tetapi faktor materi mempunyai posisi yang penting dalam menjalin dan membangun keluarga sakinah.

Umay M Ja'far berpendapat bahwa dalam kehidupan rumah tangga ternyata memang faktor ekonomi sangat penting untuk menciptakan suatu keluarga yang sakinah mawadah warahmah, tapi memang tidak bisa dipungkiri bahwa hal itu tetap otoritas Allah sebagai Maha Pemberi Rizqi. Sebab dalam Islam ternyata memang kaya dan miskin sangat erat kaitannya dengan pernikahan. ${ }^{1}$ Tetapi pada umumnya, uang merupakan penyebab terjadinya percekcokan dalam keluarga. Terlalu sedikit uang hampir selalu menimbulkan krisis dalam rumah tangga. Terlalu banyak uang dapat juga mengakibatkan gangguan fisik dan non fisik, antara lain susah tidur, penyakit jantung, darah tinggi dan berbagai penyakit lainnya. ${ }^{2}$

Kestabilan ekonomi merupakan salah satu penunjang terwujudnya keluarga sakinah. Kondisi keuangan sebuah keluarga bisa dikatakan stabil apabila terdapat keseimbangan pemasukan dan pengeluaran. Tidak sedikit kasus kegagalan menciptakan kelurga sakinah dan bahkan menjadi retak dan berantakan, terjadi dalam keadaan ekonomi keluarga yang kurang stabil. Bahkan keadaan ekonomi ini juga sering kali mempengaruhi kadar keimanan seseorang. Sebagimana yang telah disebutkan dalam hadits "kadal faqru an yakuna kufron"

$$
\text { قال رسول الله. ص.م. كاد الفقر أن يكون كفراً (الحديث) }
$$

Artinya: Sesesungtguhnya kefakiran akan berdampak pada kekufuran.

Karena itu kelurga perlu memperhatikan kestabilan ekonomi untuk mencapai predikat keluarga sakinah. Keperluan atau kebutuhan seseorang relative tidak dapat disama ratakan. Agar dapat menyeimbangkan kebutuhan dan pendapatan, seseorang minimal

${ }^{1}$ Umay, M. Ja'far Shadiq, Indahnya Keluarga Sakinah dalam Naungan al-Qur'an dan Sunnah, (Jakarta : Zakia Press, 2004), h. 15.

2 Imam Suhirman, Menuju Keluarga Sakinah Manajemen Keluarga Muslim dan Bimbingan Keluarga, (Bandung: Media Hidayah Publisher, 2005), h. 75. 
harus mampu merencanakan belanja rumah tangga, menambah semangat kerja dan meninggkatkan pendapatan. ${ }^{3}$

Diantara disyari'atkannya perkawinan adalah untuk mendapatkan ketenangan hidup, mendapatkan cinta dan kasih sayang, serta pergaulan yang baik dalam rumah tangga. Yang demikian baru dapat berjalan secara baik bila ditunjang dengan tercukupinya kebutuhan hidup yang pokok bagi kehidupan rumah tangga serta keadaan ekonomi yang mapan. Kewajiban nafaqah adalah untuk menegakkan dari perkawinan itu. Dengan terpenuhinya kebutuhan yang bersifat materi ditunjang dengan pemenuhan kebutuhan non materi, maka apa yang diharapkan dengan perkawinan, yaitu membentuk keluarga sakinah dapat dicapai dengan mudah.

Namun terkadang apa yang diharapkan tidak sesuai dengan keadaan, ketika nafaqah tidak terpenuhi sesuai harapan maka rumah tangga yang semula harmonis dapat menjadi rumah tangga yang mulai penuh dengan permasalahanya. Bahkan, jika tidak ditanggulangi sejak dini maka ketidak sakinahan dengan indicator perceraian bisa terjadi antara suami istri yang semula hidup dengan penuh kerukunan. Karena bagaimanapun masalah nafaqah atau masalah ekonomi merupakan penunjang hidup berumah tangga, ketika salah satu dari pasangan tidak dapat memahami akan kondisi pasangannya khususnya dalam hal ekonomi maka akan terjadi perpisahan antara suami istri. Oleh karena itu, tidak dapat dipungkiri lagi jika banyak terjadi perceraian atau ketidak harmonisan rumah tangga yang hanya dikarenakan masalah ekonomi yang kurang mapan.

Permasalahan ini yang menjadi kesenjangan akademis dan menggugah instink Quriositiy peneliti yang kebanyakan masyarakatnya adalah masyarakat urban yang dibilang cukup mapan, namun ada juga sebagian masyarakat pra sejahtera yang cukup memprihatinkan dari segi ekonominya. Sehingga peneliti mencoba untuk meneliti tentang bagaimana upaya kelurga pra sejahtera dalam mewujudkan keluarga sakinah dengan pengahasilan ekonomi yang pas-pasan. Apakah teori (das solen) dan relitas yang terjadi (das sein) ada titik temu. 


\section{Pembahasan}

\section{A. Kondisi Objek Masyarakat}

\section{Data Penduduk (Jumlah Keluarga)}

Lokasi penelitian terletak di Kelurahan Jombatan Kecamatan Jombang Kabupaten Jombang. Sebelah Utara Kelurahan Kepanjen Sebelah Timur Kelurahan Kepanjen Dan Kelurahan Kaliwungu Sebelah Selatan Desa Plandi dan Desa Pandanwangi Sebelah Barat Desa Sengon dan Desa Jabon dengan luas 107,50 Ha. Kelurahan Jombatan terdiri dari 3 Lingkungan yaitu Lingkungan Jombatan, Lingkungan Kauman dan Lingkungan Geneng. Sedangkan jumlah penduduk Kelurahan Jombatan sampai dengan bulan September 2006 sebanyak 6.525 orang, terdiri dari laki-laki 3.021 orang dan perempuan 3.504 orang yang dibagi menjadi 1.722 KK (Kepala Keluarga).

\section{Mata Pencaharian Penduduk}

Berdasarkan data yang ada di atas bahwa letak penelitian ini di wilayah perkotaan dimana secara geografis lahan yang ada sebagaian besar dgunakan untuk instansi-instansi atau lembaga-lembaga baik negeri maupun swasta, kos-kosan, pertokoan dan pabrik-pabrik. Dan bisa dikatakan bahwasannya lahan untuk pertanian terbilang masih terbatas bahkan sempit dan jarang ditemukan. Dari sisi bisa tergambarkan kondisi masyarakat Jombatan dari sisi mata pencahariannya.

\section{Pendidikan Penduduk}

Penduduk desa Jombatan bisa terbilang masyarakat yang berpendidikan, walaupun masih ada sebagian yang masih terbilang banyak yang belum biasa menyelesaikan sampai ke jenjang perguruan tinggi. Tetapi hal ini bisa menjadi perbedaan yang signifikankalau dengan penduduk lainnya walaupun tingkat pendidikan yang sama, penduduk Jombatan terbilang penduduk yang berpengalaman tinggi karena disamping hidup di perkotaan yang menghendaki hidup untuk kompetitif tetapi mereka juga harus dituntut berfikir maju. Karena secara langsung mereka yang berpendidikan rendah bersinggungan langsung dengan para lulusan sarjana untuk bersama-sama mencari pekerjaan layak. Adapun latar belakang pendidkan penduduk desa Jombatan adalah sebagai berikut:

\section{Sektor Pembangunan}


Dari sisi bangunan peribadatan, memang di wilayah Jombatan sendiri tidak ada tempat peribadan formal selain untuk kaum muslim. Tetapi hal ini bukan berarti tidak ada pemeluk agama lain Cuma umat muslim lebih dominan. Adapun umat selain muslim ketika melakukan ritual keagamaan harus keluar Jombatan, karena tempat peribadatan mereka berada di luar Jombatan.

\section{B. Pemaparan dan Analisis Data}

\section{Penyajian Data}

Dalam setiap prosesi perkawinan yang dilakukan oleh anak cucu adam mempunyai orentasi dan tujuan yang berbedabeda dalam memaknai sebuah tujuan perkawinan, ada yang mengatakan bahwa biologis mejadi faktor tujuan utama dalam sebuah perkawinan. Hal ini sebagaimana yang diungkapkan oleh Sigmund frued, bahwa instink manusia pada dasarnya selalu bertendensi pada seksualitas. Ada juga yang mengatakan bahwa faktor psikologis yang meliputi rasa ingin dicintai dan mencintai (afeksionis) dan safety need yaitu ingin mendapatkan keamanan dan perlindungan serta kenyamanan dijadikan sebagai faktor utama. Menurut pemahamn kami bahwa tujuan tersebut hanya berangkat dari subyektifitas pasangan yang menjalani. Sehingga konsepsi demikian memungkinkan untuk diintegrasikan dengan sebuah konsep yang sudah di tawarkan dalam Al-Qur'an. Yaitu terbentuk dan terwujudnya sebuah rumah tangga yang sakinah mawadah wa rahmah yang di ridholi oleh Allah swt. Stateman ini merupakan break down dari surat al-Rum ayat 21. Ketika perkawinan dimaknai sebagai sebuah perjanjian yang suci dan agung, maka sebagai konsekuensi hukumnya, bercerai atau menghancurkan keutuhan rumah tangga adalah perbuatan yang paling dibenci oleh Allah. (makruh) Karena dianggap sudah menodai sebuah perjanjian yang sakral dan suci.

Namun Ironisnya, bagaimana yang terjadi di masyarakat kita? Berdasarkan observasi yang kami lakukan di Pengadilan Agama Jombang bahwa angka percerain yang terjadi cenderung semakin tahun semakin meningkat. Ini artinya bahwa pemahaman masyarakat kita tentang perkawinan adalah perjanjian yang sangat sakral ternyata masih dianggap profan. 
Adapun tingginya angka percerain yang terjadi di kabupaten Jombang secara tidak langsung berarti mengindikasikan bahwa masyarakat Jombang kebanyakan rumah tangganya kurang harmonis sehingga berdampak pada ketidak sakinahan keluarga itu sendiri. Berdasarkan observasi yang kami lakukan di Pengadilan Agama Jombang bahwa faktor yang paling dominan mempengaruhi tingginya angka percerain adalah faktor ekonomi di antara faktor-faktor yang lainya. Hal ini Sebagaimana yang dikatakan Mufidah Ch dalam bukunya psikologi keluarga Islam berwawasan gender. bahwa Salah satu modal dasar seseorang berumah tangga adalah tersedianya sumber penghasilan yang jelas untuk memenuhi bebutuhan hidup secara finansial. Kelangsungan hidup keluarga antara lain ditentukan oleh kelancaran ekonomi, sebaliknya kekacauan dalam keluarga dipicu oleh ekonomi yang kurang lancar. ${ }^{4}$

Memotret kehidupan masyarakat kelurahan Jombang yang tepatnya berada di kota Jombang yang cenderung mayoritas masyarakatnya adalah sejahtera dan mewah, dan berpendidikan tinggi. Akan tetapi dibalik kesejahteraan dan kemewahan tersebut masih ada masyarakat yang tergolong pra sejahtera atau miskin dan terbelakang. Data ini kami dapatkan dari kantor kelurahan dan ibu-ibu kader dusun yang aktif di PKK, yang mengatakan bahwa keluarga pra sejahtera adalah keluarga yang seharinya hanya mampu makan sekali kadang kalau ada rizki lebih bisa makan dua kali., Apabila sakit tidak mampu berobat kebalai kesehatan kecuali dengan ASKIN (asuransi kesehatan). Dan tempat tinggal mereka atap dan dindingnya masih belum layak atau masih terbuat dari kayu. Secara teoritik, keluarga yang mereka bangun akan berdampak pada ketidak sakinahan sehingga terjadi percerain. Sebab posisi ekonomi dalam bangunan rumah tangga sakinah benar-benar mempunyai pengaruh yang cukup urgen.

Berdasrkan observasi yang kami lakukan di lapangan, bahwa masyarakat pra sejahterah yang ada di kelurahan Jombatan dan kabupaten Jombang adalah orang yang tergolong paling melerat dan wajib dibantu. dari segi ekonomi. Namun kenapa kemudian kehidupan rumah tangga yang dibangun oleh

${ }^{4}$ Mufidah CH, Psikologi Keluarga Islam Berwawasan Gender, (Malang : UIN Malang Press, 2008), h. 196. 
keluarga pra sejahtera di kelurahan jombatan kabupaten Jombang sangat berbeda dengan teori yang sudah ditetapkan oleh para pakar, yaitu factor ekonomi mempunyai peran yang cukup urgen dalam pembentukan keluarga sakinah mawwadah wa rahmah. Akan tetapi Bagi keluarga pra sejahtera, ekonomi bukanlah factor utama dalam pembentukan kesakinahan suatu keluarga. Jadi tidak ada istilah keharmonisan rumah tangga rusak disebabkan penghasilan mereka yang pas-pasan. Dari pengumpulan data yang kami lakukan dengan observasi dan dokumentasi dapat diambil sebuah hipotesis 'bahwa kehidupan keluarga pra sejahtera dengan ekonomi pas-pasan mampu mewujudkan sebuah rumah tangga yang sakinah mawwadah wa rahmah. Sebagai pendukung dari observasi dan dokumentasi yang kami lakukan di lapangan, jurnal dan buku. Maka kami akan menyajikan data dari hasil interview yang sudah kami lakukan dengan keluarga pra sejahtera.

\section{Analisis Data}

Dari penyajian data yang sudah kami sajikan diatas, kami mencoba menganalisis berbagai permasalahan terkait bagaimana konsep keluarga sakinah dalam prespektif kelurga pra sejahtera. Setiap orang mempunyai kebutuhan terutama yang berhubungan dengan sandang, pangan, dan papan. Hal ini disebut kebutuhan primer, fisiologis, atau jasmaniah. Bagi keluarga modern, selain kebutuhan tersebut diatas diperlukan pula pemenuhan kebutuhan dalam hal kesehatan, pendidikan, rekreasi, transpotasi dan komunikasi. Bagi sekunder, psikologis dan ruhaniyah. Sedangkan bagi keluarga modern yang tergolong kebutuhan sekunder seperti rasa aman, penghargaan atas prestasi yang dicapainya, adan aktualisasi diri. Kestabilan ekonomi dapat merupakan salah satu faktor yang ikut menentukan kebahagian dan keharmonisan keluarga. Agar ekonomi keluarga stabil diperlukan antara lain perencanaan anggaran keluarga dan keterbukaan/kejujuran dalam hal keuangan antar anggota keluarga.

Dalam berbagai literature dikakatakan bahwa ekonomi mempunyai posisi penting dalam pembentukan keluarga sakinah, hal ini sebagaimana yang dikatakan oleh Umay M Ja'far bahwa dalam kehidupan rumah tangga ternyata memang faktor 
ekonomi sangat penting untuk menciptakan suatu keluarga yang sakinah mawadah wa rahmah ${ }^{5}$.ini artinya bahwa Salah satu modal dasar seseorang berumah tangga adalah tersedianya sumber penghasilan yang jelas untuk memenuhi bebutuhan hidup secara finansial. Kalangsungan hidup keluarga antara lain ditentukan oleh kelancaran ekonomi, sebaliknya kekacauan dalam keluarga dipicu oleh ekonomi yang kurang lancer. Karena itu rasulullah menyarankan kepada pemuda dan pemudi yang telah siap secara mental, ekonomi, dan tanggung jawab serta berkeinginan untuk segera menikah. Jika belum bersiap, maka dianjurkan untuk berpuasa. Sebagaimana dinyatakan dalam Hadist Nabi:

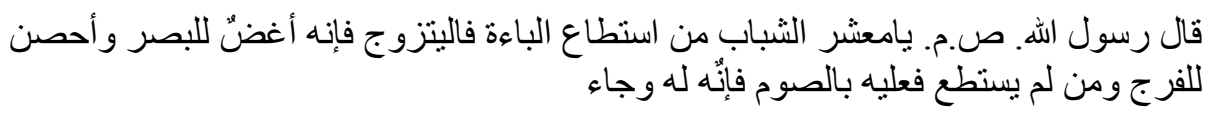

Artinya: "Dari Abdullah bin mas'ud, Rasulullah bersabda Wahai para pemuda, barang siapa diantara kalian yang telah sanggup menikah, maka hendaklah menikah. Sesungguhnya menikah itu dapat menghalangi pandangan dan memelihara kehormatan. Barang siapa

Dapat dipahami dari hadits ini bahwa, yang dimaksud kemampuan atau man istatho'a disini adalah, kemampuan dari segi lahir dan bathin, yang termasuk di dalamnya adalah kemampanan ekonomi. Ini artinya bahwa rosul sendiri cukup memandang bahwa faktor ekonomi mempunyai peran penting dalam gerbang pembentukan keluarga sakinah mawadah wa rahmah. Ini kemudian dalam ajaran islam dikenal istilah budaya mahar yang tidak lain adalah berfungsi sebagai pembuktian bahwa sebelum menikah seseorang laki-laki harus siap secara matang baik mental maupun ekonomi. Sehingga dalam hal ini Islam tidak menghendaki kemiskinan terjadi dalam sebuah rumah tangga, sebab dampak kefakiran tidak hanya memicu tindakan criminal tetapi juga dekat dengan kekufuran. Sebagaimana yang disabdakan Nabi Muhammad saw.

${ }^{5}$ Umay, M. Ja'far Shadiq, Indahnya Keluarga Sakinah dalam Naungan al-Qur'an dan Sunnah, (Jakarta : Zakia Press, 2004), h. 15. 


$$
\text { قال رسول الله. ص.م. كاد الفقر أن يكون كفراً (الحديث) }
$$

Artinya: "Sesesungtguhnya kefakiran akan berdampak pada kekufuran".

Dalam hubungan suami istri dalam rumah tangga tidak lepas dari hak dan kewajiban antara suami dan istri. Adanya hak dan kewajiban antara suami dan istri dalam kehidupan rumah tangga itu dapat dilihat dalam beberapa ayat al-Qur'an dan beberapa hadits Nabi. Sebagaimana misalnya ayat dalam al-Qur'an Surat alBaqarah ayat 286:

$$
\text { ولهن منل الذي عليهن با لمعروف وللرجال عليهن درجة }
$$

Artinya : "Bagi istri itu ada hak-hak berimbang dengan kewajibankewajibannya secara ma'ruf dan bagi suami setingkat lebih dari istri" (QS. Al-Baqarah Ayat 286). ${ }^{6}$

Adapun salah satu kewajiban suami yaitu pemberian nafaqah kepada istri secara patut. Nafaqah merupakan kewajiban suami terhadap istrinya dalam bentuk materi, karena kata nafaqah itu sendiri berkonotasi materi. Dengan demikian, nafaqah istri berarti pemberian yang wajib dilakukan oleh suami terhadap istrinya dalam masa perkawinannya. Yang termasuk dalam pengertian nafaqah menurut yang disepakati ulama' ialah belanja untuk keperluan makan yang mencakup sembilan bahan pokok pakaian dan perumahan atau dalam bahasa sehari-sehari disebut dengan sandang, pangan dan papan. Hukum membayar nafaqah untuk istri, baik dalam bentuk pembelanjaan, pakaian adalah wajib. Dan kewajibannya suami dalam hal nafaqah ini dijelaskan dalam alQur'an surat al-Baqarah ayat 233:

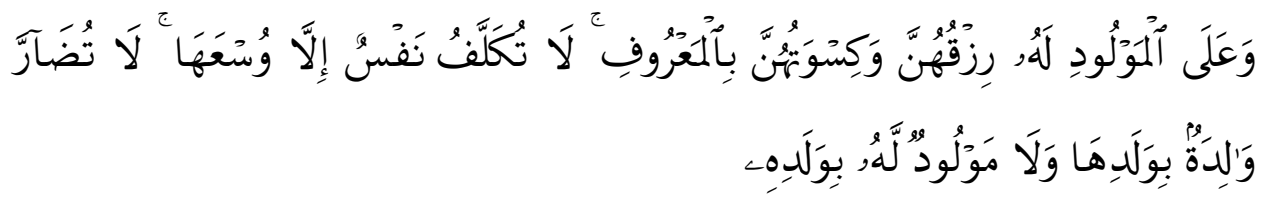

Artinya : "Kewajiban ayah untuk memberikan belanja dan pakaian untuk istrinya. Seseorang tidak dibebani kecuali semampunya, seorang ibu tidak akan mendapat kesusahan karena anaknya, dan seorang ayah tidak akan mendapat kesusahan karena anaknya" (QS. al-Baqarah ayat $233)^{7}$

${ }^{6}$ Ibid, h. 159.

7 Ibid, h. 166. 
Dalam ayat ini dijelaskan bahwa memang kewajiban memberikan nafaqah kepada keluarga adalah dibebankan kepada suami, tetapi kewajibannya tetap disesuaikan dengan tingkat kemampuan ekonomi suami itu sendiri

Dari das sein yang kami paparkan diatas dapat diambil suatu kesimpulan, bahwa ekonomi yang meliputi sandang pangan dan papan mempunyai posisi yang urgen dalam pembentukan rumah tangga. Namun yang menjadi pertanyaan serius adalah, bagaimana kehidupan rumah tangga keluarga pra sejahtra yang tergolong dari faktor ekonomi memang sungguh sangat mengkhawatirkan dan tidak mampu.

Kaitanya dengan keluarga pra sejahtera dalam pembentukan keluarga sakinah mawadah wa rahmah merupakan suatu keniscayaan atau deterministic, bila dibenturkan dengan teori dan hadits yang telah kami sebutkan, sebab kalau kita kaji secara etimologi pra berarti sebelum atau belum, sedangkan sejahtera adalah rasa aman damai dan sentosa. Bila digabungkan berarti belum ada rasa aman damai dan sentosa. Dari etimologi ini mengindikasikan bahwa ruh keluarga sakinah memang tidak akan dapat dirasakan oleh kalangan keluarga pra sejahtera. Sebab menurut data yang peneliti dapatkan dari ketua kader dusun ibu Mulyanto, mengatakan "terkait denga katagorisasi keluarga pra sejahtra adalah keluarga yang hanya mampu makan sehari sekali, keluarga yang apabila sakit tidak mampu untuk pergi kebalai pengobatan kecuali dengan ASKIN (asuransi kesehatan), Keluarga yang tidak mampu menyekolahkan anaknya dari umur 7-15 tahun., keluarga yang tidak mempunyai penghasilan tetap, kalo ada itupun hasilnya pas-pasan, dan Keluarga yang atap dan dinding rumahnya tidak layak atau tidak mempunyai strandar kelayakan

Namun berdasrkan data interview yang kami dapatkan di kelurahan jombatan, dari jumlah penduduk 6.525 orang, terdiri dari laki-laki 3.021 orang dan perempuan 3.504 orang yang dibagi menjadi 1.722 KK (Kepala Keluarga). Terdapat lima keluarga pra sejahtra yang tergolong paling miskin.ternyata mereka mepunyai pandangan yang berbeda terkait dengan konsep keluarga sakinah, hal ini sebagaimana hasil interview yang kami dapat dilapangan terkait dengan bagaimana konsep keluarga bahagia sakinah mawadah wa rahmah menurut bapak dan ibu? Wal hasil sebagian 
besar mereka menjawab "keluarga sakinah adalah keluarga yang penuh pengertian antra kedua pasangan dan tidak adanya cekcok rumah tangga dan adanya komunikasi yang sehat.

Dapat dianalisis bahwa, berdasarkan pertanyaan interview yang kami lontarkan kepada mereka, ternyata keluarga sakinah menurut mereka adalah kebahagiaan yang sifatnya inmateri bukan materi. Ini artinya bahwa bagi keluarga pra sejahtra yang berdomisili dikelurahan jombatan, faktor ekonomi yang dinilai mempunyai posisi urgen dalam pembentukan keluarga sakinah, ternyata tidak dipandang begitu penting. Walaupun pada aplikasinya kadang ekonomi juga harus tetap diperhitungkan dan dipikirkan sebab ini merupakan basic need manusia untuk bertahan hidup. Namun ekonomi bukanlah penghalang terhadap terbentuknya runmah tangga yang sakinah mawadah wa rahmah.

Analisis ini didukung dengan hasil pertanyaan interview, yang kami lontorkan kepada salah satu keluarga pra sejahtra, yang bernama bapak kusnadi dan istrinya ibu Rodliyah, dengan pertanyaan bahwah Apakah bapak/ibu pernah mengalami keretekan rumah tangga yang disebabkan karena faktor penghasilan yang pas-pasan? Bagaimana solusi atau jalan keluar? Kata bapak Kusnadi dan Ibu Rodliyah; ga tahu mas. Ibu'e wes paham kondisi kulo. (tidak perna mas, ibunya sudah paham kondisi dan kemampuan saya) Begitu juga keluraga pra sejahtra yang lainya. Mengatakan hal yang sama bahwa mereka pernah mengalami ckcok rumah tangga namun bukan karena faktor ekonomi. Dan ketika kami menanyakan "apakah bapak ibu sudah cukup bahagia dengan kondisi yang seperti ini. Berdasrkan data yang ada, merekapun rata-rata menjawab cukup bahagia dengan kondisi yang seperti ini. Artinya mereka mensyukuri apa-apa yang sudah digariskan Tuhan sama mereka.

Lantas bagaimana upaya keluarga pra sejahtra terhadap pembentukan keluarga sakinah? Dari hasil interview yang kami dapatkan bapak dan ibu Bandi, dengan pertanyaan "Bagaimana upaya bapak/ibu dalam membentuk keluaga sakinah dengan penghasilan yang pas-pasan? apakah ini cukup berpengaruh terhadap kesakinahan keluarga atau kebahagian keluarga? mengatakan "Masio penghasilan bapak e pas-pasan mboten menopo, soale tentreme rumah tangga niku boten sakinah dunyo mawon tapi saling pengertian lan podo nerimo podo mbatnu. 
(walaupun penghasilan bapaknya pas-pasan tidak apa-apa, karena tentremnya hati itu bukan hanya faktor dunia saja, tapi yang paling penting adalah saling membantu satu sama lain), sedangkan untuk keluarga bapak zainul menjawab "Ngge mboten pengaruh pokok'e saling ngerteni wontene pinten ngge niku dicukup-cukupaken.ha yang serupa juga (ya tidak pengaruh, pokoknya saling mengerti, adanya berapa ya dicukup-cukupkan) .adapun untuk keluarga bapak kusnadi mejwab "Seng penting iku Syukur mas!!! Penghasilan piro ae nek gak disyukuri yo tetep kurang!Alhamdulillah selama iki ga tahu ono masalah rumah tangga gara-gara faktor penghasilanku seng ga jelas utowo paspasan.(yang penting itu syukur mas, penghasilan berapa aja, kalau tidak syukuri ya ttap kurang, Alhamdulillah selama ini dengan penghasilan yang pas-pasan seperti ini tidak pernah ada masalah yang membuat hubungan ini retak).

Berangkat dari das solen dan das sein yang ada diatas, bahwa ternyata kemapanan ekonomi yang dianggpap dalam teori merupakan faktor penting dalam membentuk keluarga sakinah mawadah wa rahmah, namun pada kenyataanya yang kami temukan di lapangan, ternyata bagi masyarakat keluarga pra sejahtra faktor ekonomi tidak di anggap cukup signifikan dalam pembentukan keluarga sakinah. Hal ini terbukti dengan data interview yang kami dapatkan di lapangan, yaitu di kelurahan jombatan kabupaten Jombang.

Menurut analisis kami, bahwa yang menjadikan faktor terbentuknya keluarga sakinah dalam prespektif keluarga pra sejahtra adalah adanya kasih sayang dan pengertian antara kedua pasangan terkait dengan penghasilan suami yang serba pas-pasan serta adanya rasa syukur terhadap apa yang sudah menjadi garis ketentuan Allah. Dan yang terahir adalah adanya mangemen konflik yang bagus dan komunikasi yang sehat. Walaupun kadang dalam aplikasinya faktor materi merupakn faktor yang tidak bisa di pungkiri lagi urgensitasnya dalam kebutuhan sehari-hari. Dan ini merupakan naluri manusia yang mempunyai kecenderungan untuk bertahan hidup. Sebab kebutuhan sandang panagan papan merupakan kebutuhan dasar manusia (basic need) sebagai upaya untuk mempertahankan hidupnya. Namun itu semua tergantung bagaimana seseorang tersebut menempatkan posisi materi pada kebutuhan dan keinginan. 
Konsep keluarga yang ideal seperti ini sebenarnya sudah dijelaskan dalam al-Quran yaitu dengan istilah sakinah mawadah warahmah. Yang dijelaskan dalam surat ar- rum ayat 21

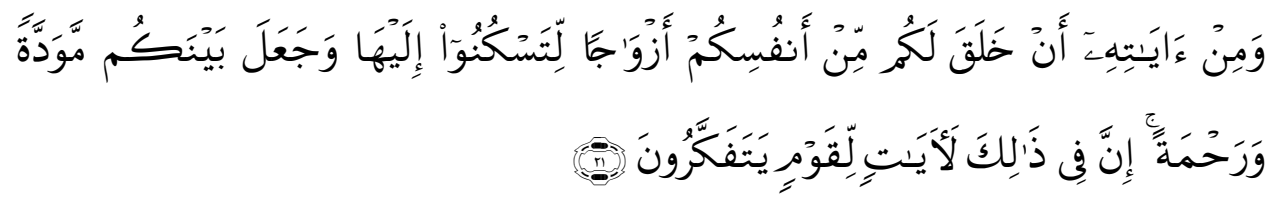

Artinya: "Dan di antara tanda-tanda kekuasaan-Nya ialah Dia menciptakan untukmu isteri-isteri dari jenismu sendiri, supaya kamu cenderung dan merasa tenteram kepadanya, dan dijadikanNya diantaramu rasa kasih dan sayang. Sesungguhnya pada yang demikian itu benar-benar terdapat tanda-tanda bagi kaum yang berfikir." (QS. Ar-Rum Ayat 21). ${ }^{8}$

Dari ayat di atas dapat dipahami, bahwa dengan landasan cinta dan kasih tersebut, system kehidupan yang dijalani suami istri dalam rumah tangganya harus pula dilalui oleh proses yang sehat. Cara-cara yang sehat dalam relasi suami istri dalam kehidupan perkawinan tersebut harus dilakukan dengan sikap saling memberi dan menerima secara ikhlas, saling menghargai, saling memahami kepentingan masing-masing tanpa paksaan dan kekerasan. ${ }^{9}$

\section{Simpulan}

Hasil penelitian ini menyatakan bahwa pada dasaarnya ekonomi tidak mempunyai posisi penting dalam pembentukan keluarga sakinah bagi keluarga pra sejahtera. Meski demikian secara teoritik mengatakan bahwa ekonomi merupakan faktor yang paling menunjang terhadap terbentuknya keluarga sakinah dengan indikasi beberapa point penting, diantaranya : Pertama; konsep yang diterapkan keluarga pra sejahtra dalam membangun keluarga sakinah adalah dengan selalu menanamkan rasa syukur terhadap apa yang sudah diberikan atau dikaruniakan oleh Allah swt. Serta selalu Qona'ah dengan penghasilan yang didapatkan suami dan tidak pernah mengeluh dengan semua kesusahan dalam keluarga. Serta memandang kesusahan sebagai kebahagian. Kedua; faktor-faktor yang

8 Ibid, h. 260.

${ }^{9}$ Mufidah CH, h. 150. 
yang paling dominan mempengaruhi kesakinahan dalam rumah tangga adalah faktor spritual dan material. Namun dalam prespektif keluarga pra sejahtra faktor spritual yang dianggap mempunyai posisi urgen dalam pembentukan kesakinahan rumah tangga. Ketiga; upaya keluarga pra sejahtra dalam mewujudkan keluarga sakinah adalah dengan cara saling mengerti dan memahami antara kedua pasangan khususnya dalam masalah penghasilan sehari-hari. Serta yang paling penting adalah dengan cara membentengi keluarga dengan pesan moral dan spiritual.

\section{DAFTAR PUSTAKA}

Departeman pendidikan dan kebudayaan, Al-Qur'an dan Terjamahannya (Revisi terbaru) DEPAG RI. Semarang, CV. Asy Syifa', 1999.

Derektorat Jenderal Bimbingan Masyarakat Islam dan Penyelenggaraan Haji, 2003.

Imam Suhirman, Menuju Keluarga Sakinah Manajemen Keluarga Muslim dan Bimbingan Keluarga. Bandung, Media Hidayah Publisher, 2005.

Membina keluarga Sakinah, Jakarta: PT. Prenada Media

Mufidah CH., Psikologi Keluarga Islam Berwawasan Gender. UIN Malang Press, 2008.

Umay, M. Ja'far Shadiq, Indahnya Keluarga Sakinah dalam Naungan alQur'an dan Sunnah, Jakarta: Zakia Press, 2004. 